\title{
Anatomical, Histochemical and Biological Studies of Clusia grandiflora Splitg. (Clusiaceae)
}

\author{
Mariana Martinelli Junqueira Ribeiro ${ }^{1,2,3^{*}}$ \\ https://orcid.org/0000-0002-7677-2889
}

Karla Marins Mattos da Silva ${ }^{4}$

https://orcid.org/0000-0003-3925-5492

Louise Azulay Palavecino 5

https://orcid.org/0000-0003-4563-9708

Laine Celestino Pinto ${ }^{6}$

https://orcid.org/0000-0003-4246-5714

\section{Bruno Leal Alves Ferreira ${ }^{5}$}

https://orcid.org/0000-0001-9274-6069

\section{Adriana Quintella Lobão}

https://orcid.org/0000-0003-4036-2367

\author{
Helena Carla Castro 5 \\ https://orcid.org/0000-0001-5283-1541
}

Raquel Carvalho Montenegro ${ }^{7}$

https://orcid.org/0000-0002-3861-293X

\author{
Claudia Franca Barros 4 \\ https://orcid.org/0000-0002-4973-4326
}

Ana Joffily ${ }^{2}$

https://orcid.org/0000-0002-1467-0203

\author{
Alessandra Leda Valverde ${ }^{3}$ \\ https://orcid.org/0000-0002-1250-1051 \\ Selma Ribeiro de Paiva ${ }^{1,2}$ \\ https://orcid.org/0000-0002-8295-7011
}

${ }^{1}$ Fluminense Federal University, College of Pharmacy, Postgraduate Program in Applied Sciences for Health Products, Niterói, Rio de Janeiro, Brazil; ²Fluminense Federal University, Institute of Biology, General Biology Department, Botany Sector, Niterói, Rio de Janeiro, Brazil; ${ }^{3}$ Fluminense Federal University, Institute of Chemistry, Department of Organic Chemistry, Laboratory of Marine Natural Products, Niterói, Rio de Janeiro, Brazil; ${ }^{4 B}$ Botanical Garden of Rio de Janeiro Research Institute, Laboratory of Structural Botany, Rio de Janeiro, Rio de Janeiro, Brazil; ${ }^{5}$ Fluminense Federal University, Institute of Biology, Laboratory of Antibiotics, Biochemistry, Teaching and Molecular Modeling, Niterói, Rio de Janeiro, Brazil; ${ }^{6}$ Federal University of Pará, Institute of Biological Sciences, Laboratory of Human Cytogenetics, Belém, Pará, Brazil; 7 Federal University of Ceará, Drug Research and Development Center (NPDM), Faculty of Medicine, Fortaleza, Ceará, Brazil.

Received: 2019.11.12; Accepted: 2020.04.17.

*Correspondence: mari_ribeirobr@yahoo.com.br; Tel.: +55-21-26299952 (M.M.J.R)

HIGHLIGHTS

- Vascular system with accessory bundles in the petiole.

- Alkaloids, phenols substances, carbohydrates and lipids were located.

- Stems and leaves ethanolic extracts with cytotoxic activity.

- Adventitious roots, stems and leaves ethanolic extracts with antibacterial activity.

Abstract: Clusia grandiflora belongs to an important botanical family which is known for its medicinal value, however there are few reports in literature about the species, highlighting the relevance of this study. Anatomical studies with leaves and stems were performed using traditional techniques. In this investigation it was identified particularities of the species such as the presence of vascular system arranged in an opened arc-shaped with the flexed ends towards the inside of the arch with accessory bundles in the petiole. In 
histochemical studies, performed with different reagents, alkaloids, phenols substances, carbohydrates and lipids were located. The cytotoxic activity of the extracts was performed by tetrazole salt and showed promising results for ethanolic extracts of stems ( $\mathrm{IC}_{50}$ human colon cells of $24.30 \mu \mathrm{g} / \mathrm{mL}$ ) and leaves $\left(\mathrm{IC}_{50}\right.$ ascites gastric cells of $44.15 \mu \mathrm{g} / \mathrm{mL}$ ), without cell membrane disruption of erythrocytes. The antibacterial activity was evaluated by tryptic soy agar and minimal inhibitory concentration assays and showed positive results for Pseudomonas aeruginosa and Escherichia coli, with better result for adventitious roots $(32 \mu \mathrm{g} / \mathrm{mL}$ and $16 \mu \mathrm{g} / \mathrm{mL}$, respectively), stems $(64 \mu \mathrm{g} / \mathrm{mL}$ and $32 \mu \mathrm{g} / \mathrm{mL}$, respectively) and leaves $(64 \mu \mathrm{g} / \mathrm{mL}$ and 32 $\mu \mathrm{g} / \mathrm{mL}$, respectively) ethanolic extracts. Thus, these studies were able to characterize the species and show its potential as promising source of active substances.

Keywords: antibacterial activity; cytotoxic activity; histochemical evaluation; plant anatomy.

\section{INTRODUCTION}

The family Clusiaceae Lindl. includes 15 genera, 800 species and present wide geographical distribution, being more recurrent in the tropics [1]. The genus Clusia L. comprises $66 \%$ of the species and most of them exhibit xerophytic anatomical features [1,2], in addition to secondary metabolites with different activities, such as antinociceptive flavonoids, larvicidal terpenoids and benzophenones with antimicrobial and antitumor activities [3-6].

Studies with Clusia grandiflora Splitg. showed that the floral resins [7,8] and benzophenones isolated from the trunk latex [9] presented antimicrobial activity and ethanolic extracts demonstrated antioxidant potential that could be associated with presence of phenolic compounds [10].

Due to the few reports in literature about $C$. grandiflora, anatomical, chemical and biological studies are necessary. Select markers that can serve as control [11] and identify phylogenetic relationships [12] are the initial step to plant studies, being the anatomical and histochemical studies useful for this purpose. As $C$. grandiflora is a tree species, native from Brazil and from a botanical family with biological potential [3-6], it could be a promising source of substances that can act as a prototype in the pharmaceutical industry.

Cancer is the second cause of death in worldwide [13] and represents a complex disease in which cells undergo that lead to uncontrolled multiplication. Patients affect by the disease are normally debilitated, with reduced immunity due to the chemotherapy treatment and often more susceptible to opportunistic infections [14]. Species of the genus Clusia had already evidenced antitumor activity [4] and the possibility of having a dual inhibitor to act as an anticancer and antibacterial may be an alternative treatment for the patients with both diseases [15].

Thus, this work aimed to perform anatomical and histochemical studies in the stems and leaves of $C$. grandiflora and evaluate the cytotoxic and antibacterial activity of the hexanic and ethanolic crude extracts of the adventitious roots, stems, leaves and flowers in order to support the search for new substances and contribute to the knowledge of the Brazilian flora.

\section{MATERIAL AND METHODS}

\section{Plant material}

Adventitious roots, stems, leaves and flowers of $C$. grandiflora were collected near the Rio de Janeiro Botanical Garden Research Institute, Rio de Janeiro, Brazil. The identification was carried out by the botanist Adriana Quintella Lobão and a specimen was deposited in the Jardim Botânico do Rio de Janeiro Herbarium (RB 603161). For the accomplishment of the chemical and biological studies, CGEN authorization was obtained (CGEN no 010415/2013-0/ SISGEN A3E1AD0). For anatomical description and histochemical analysis, only leaves and stems were used while for the evaluation of biological activity, all parts collected were used.

\section{Anatomical description}

Transverse sections at the middle part of the midrib and intercostal regions of leaf and the middle region of the petiole and stems were made and fixed in alcohol $70 \%$. The petiole and stem were embedded in polyethylene glycol (PEG) as proposed by Burger and Richter [16] and leaf blade in historesin (Leica). Posteriorly, transverse serial sections ( $3-5 \mu \mathrm{m}$ thick) were performed in rotary microtome (RMC Products MT990) and stained with Astra Blue (Sigma-Aldrich) and Basic Fuchsin (Vetec) [17]. The stained sections 
were made into semi-permanent slides with glycerin $50 \%$ for viewing and photography in an optical microscope (Zeiss Primo Star).

\section{Histochemical analysis}

Free-hand section in the fresh stems and leaves were performed in order to identify different chemical metabolites. Leaves were embedded in historesin (Leica) and sectioned in rotary microtome (RMC Products MT990) for observation with fluorophores reagents. Materials were prepared using different reagents for the identification of primary and secondary metabolites as described in Table 1.

Semi-permanent slides were made using the stained sections with glycerin $50 \%$ for visualization and photography in optical microscope (Zeiss Primo Star). Stained sections with fluorophore Auramine $\mathrm{O}$ (Excitation 450-480 nm/ Emission $515 \mathrm{~nm}$ ) and Calcofluor (Excitation 360-370 nm/ Emission $420 \mathrm{~nm}$ ) were visualized and photographed in fluorescence microscopy with LAS AF LITE software (version 2.6.0) (Leica Microsystems) and laser scan confocal (Leica TCS SPE) coupled to camera CoolSnap attached to an Olympus $50 \mathrm{BX}$.

\section{Preparation of the extract}

Vegetative and reproductive organs were dried in oven with forced air circulation (Solab SL) at $40^{\circ} \mathrm{C}$ and later reduced to small fragments with the use of the blender (Tron). The processed material was submitted to extraction by static maceration with hexane (VETEC) and ethanol (VETEC). The solvent was removed in rotary evaporator (Buchi $\mathrm{R} 114$ ).

\section{Cytotoxic activity against cancer cell lines}

The in vitro cytotoxicity of the extracts were tested against tumor cell lines (HCT-116 = human colon, AGP-01 = malignant gastric ascites, MCF7 = breast-human) and human fibroblast cell line (MRC5 = human fibroblast) and determined by tetrazole salt (MTT) [3-(4,5-dimethyl-2-thiazolyl)-2,5-diphenyl-2H-tetrazolium bromide] following the methodology proposed by Mosmann [18], with modifications. Cell $\left(5 \times 10^{3}\right.$ cells per well) were plated in 96-well plate and incubated with $50 \mu \mathrm{g} / \mathrm{mL}$ of extracts for $72 \mathrm{~h}$ and then centrifuged. The supernatant was aspirated and added to $100 \mu \mathrm{L}$ MTT solution $0.5 \mathrm{mg} / \mathrm{mL}$ in Dulbecco's modified Eagle culture medium (DMEM).

Plates were placed in an oven at $5 \% \mathrm{CO}_{2}$ for $3 \mathrm{~h}$ and then centrifuged and the supernatant was aspirated. The precipitate was resuspended in $100 \mu \mathrm{L}$ of dimethyl sulfoxide (DMSO) and agitated for 10 min until complete dissolution of the formazan crystals. Plates were analyzed in a spectrophotometer at a wavelength of $570 \mathrm{~nm}$. Doxorubicin was used as a positive control and DMSO as a negative control. $\mathrm{IC}_{50}$ was calculated by non-linear regression in the GraphPad Prism 6.0 software. The most active extracts had their concentration-response curve $(0.78125 \mu \mathrm{g} / \mathrm{mL}-50 \mu \mathrm{g} / \mathrm{mL})$ evaluated.

\section{Cell membrane disruption}

The test cell membrane disruption was performed in 96-well plates using a $2 \%$ mouse erythrocyte suspension in $\mathrm{NaCl} 0.85 \%$ containing $\mathrm{CaCl}_{2} 10 \mathrm{mM}$. Erythrocytes were plated together with extracts in triplicate at a concentration of $200 \mu \mathrm{g} / \mathrm{mL}$. Plates were incubated for $1 \mathrm{~h}$ under stirring and then centrifuged. The supernatant was transferred to plate and read in a spectrophotometer at the wavelength of $450 \mathrm{~nm}$. Triton X-100 (0.5\%) and DMSO were used as positive and negative controls, respectively. $\mathrm{IC}_{50}$ was calculated like effective dose that induced lyses in $50 \%$ of the Triton X-100.

\section{Antibacterial activity}

The sensitivity profile of extracts against Gram-positive (Enterococcus faecalis, Staphylococcus aureus, Staphylococcus epidermidis and Staphylococcus simulans) and Gram-negative (Serratia marcescens, Proteus mirabilis, Enterobacter cloacae, Pseudomonas aeruginosa, Escherichia coli and Klebsiella pneumoniae) bacterial strains was evaluated. After $5 \mathrm{~h}$ of growing the bacterial inoculum was adjusted to 0.5 McFarland scale. Plates were homogeneously seeded with the inoculum and the discs containing $5 \mu \mathrm{L}(5$ $\mathrm{mg} / \mathrm{mL}$ ) of each extract, negative control (DMSO) and positive controls (Vancomycin and Ciprofloxacin for Gram positive and negative strains, respectively) were deposited on the surface. Plates were stored overnight in an oven at $35^{\circ} \mathrm{C}$. The tests were performed in triplicate and the extracts without bacterial growth had their inhibition diameter halos measured in millimeters. 
The extracts that exhibited activity were submitted to the minimal inhibitory concentration (MIC) test according to the methodology proposed by the Clinical and Laboratory Standards Institute (CLSI) (2012) [19]. Using 96-well plate the starting concentration of each tested extract was $256 \mu \mathrm{g} / \mathrm{mL}$ in the first well, following the serial dilution until $4 \mu \mathrm{g} / \mathrm{mL}$. The positive controls were serially diluted from $256 \mu \mathrm{g} / \mathrm{mL}$ until $0.25 \mu \mathrm{g} / \mathrm{mL}$. Plates were stored at $35{ }^{\circ} \mathrm{C}$ for approximately $16-20 \mathrm{~h}$ in an incubator with ambient air. The MIC was performed in triplicate and determined to the naked eye in the function of the turbidity present on the plate after the addition of the blue resazurin dye diluted in sterile distilled water $(0.1 \mathrm{mg} / \mathrm{mL})$. If there are metabolically active microorganisms, blue resazurin changes its color to pink. The first well that remained blue was determined as the minimum inhibitory concentration.

\section{RESULTS}

\section{Anatomical description}

\section{Petiole}

In cross section, the petiole of $C$. grandiflora has circular shape. The epidermis is uniseriate, glabrous and presents cuticle with flanges (Figure 1A). Cortex is composed by 10-12 annular collenchyma layers with secretory ducts of probable schizogenic origin (Figure $1 \mathrm{~A}$ ), followed by fundamental parenchyma with thin walls and varied sizes (Figure 1B). The vascular system is constituted by collateral bundles arranged in an opened arc-shaped with the flexed ends towards the inside of the arch. The vascular bundles are surrounded by perivascular fiber groups (Figure 1C). There is also the presence of accessory bundles in the region of the cortical fundamental parenchyma (Figure 1B). The xylem is composed by protoxylem and metaxylem elements arranged in radial series (Figure 1D). In the medulla region of the petiole, there are parenchyma cells of several sizes (Figure $1 \mathrm{C}$ ).

\section{Leaf blade}

The leaves are hypostomatic and the epidermis is glabrous on both sides (Figure 1E and 1F). Transverse sections show that the epidermis is uniseriate, covered with a thick cuticle that extends between the anticlinal walls and forms flanges (Figure 1E). The mesophyll is isobilateral (Figure 1E). The hypodermis presents about two layers of elliptic cells on the adaxial side and one layer of smaller cells on the abaxial side (Figure $1 \mathrm{E})$.

The palisade parenchyma presented 2-3 layers in the adaxial surface and 1-2 layer in the abaxial surface. The spongy parenchyma has large and abundant intercellular spaces and 10-12 cells layers of several sizes, where secretory ducts of probable schizogenic origin, idioblasts with druses and vascular bundles are observed (Figure 1E). 

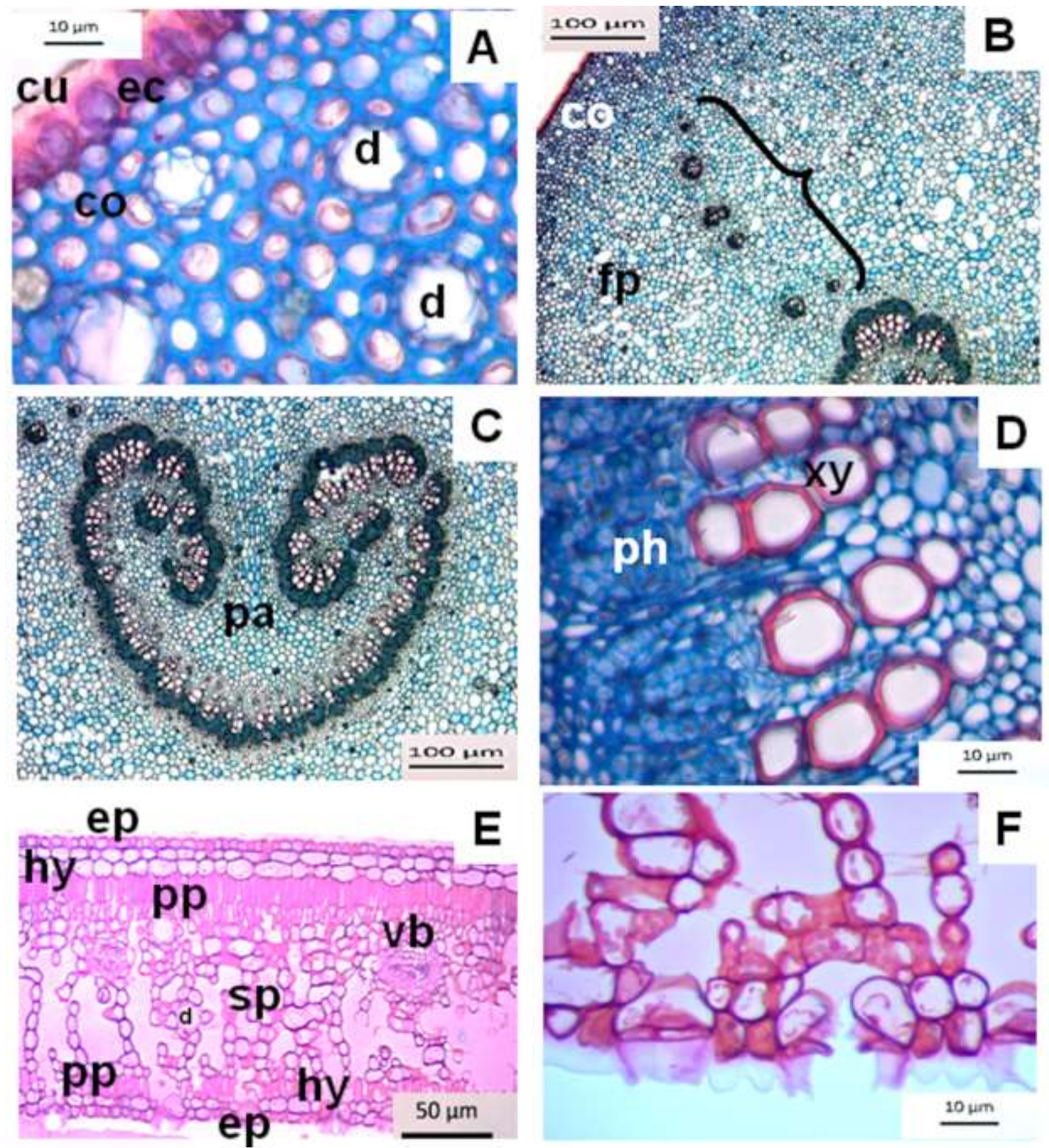

Figure 1. Leaf anatomy of Clusia grandiflora in cross-sections A-D: Petiole and E-F: Leaf blade A) Epidermis showing the cuticular flanges and secretory ducts. B) Annular collenchyma and accessory collateral bundles (bracket). C) Overview of the vascular system with parenchymal cells. D) Metaxylem elements arranged in radial series. E) Hypodermis, palisade parenchyma and secretory ducts on the spongy parenchyma F) Stomata in the abaxial surface. co: collenchyma; cu: cuticle; d: secretory ducts; ec: epidermal cells; ep: epidermis; fp: fundamental parenchyma; hy: hypodermis; pa: parenchyma cells; ph: phloem; sp: spongy parenchyma; pp: palisade parenchyma; vb: vascular bundle; $x y$ : xylem. Scale: $A, D$ and $F=10 \mu \mathrm{m} ; B$ and $C=100 \mu \mathrm{m} ; E=50 \mu \mathrm{m}$.

The edge of leaf (Figure $2 \mathrm{~A}$ and $2 \mathrm{~B}$ ) present a uniseriate epidermis with elongated cells and a thicker cuticle in relation to the other leaf parts. Also, cuticle flanges are present and occurs an impregnation of the inner periclinal walls in the epidermal cells (Figure 2A). The layers underlying, are occupied by cells of the fundamental parenchyma presenting secretory ducts of probable schizogenic origin and vascular bundle with perivascular fibers encompassing both of them (Figure 2B).

In the transverse plane, the midrib has a convex-convex shape (Figure 2C), the epidermis is uniseriate and the cuticle presents flanges and cutinized inner periclinal cell walls (Figure 2D and 2E). Below the epidermis, parenchyma layers presented several idioblasts with druses (Figure $2 \mathrm{~F}$ ) and secretory ducts also of probable schizogenic origin (Figure $2 \mathrm{G}$ ). The vascular system is formed by about 30 free circular bundles 
(Figure 2C). Groups of perivascular fibers occurred along the phloem tissue (Figure $2 \mathrm{C}$ and $2 \mathrm{H}$ ). There are 9-10 accessory bundles arranged in two bands and inserted in the medullar parenchyma (Figure 2C).

\section{Stem}

In transverse plane, the stem (Figure $2 \mathrm{I}$ and $2 \mathrm{~J}$ ) has primary tissues and early secondary growth. Uniseriate epidermis is observed with cells of irregular shape covered by thick cuticle (Figure 2I). The cortex is formed by parenchyma cells layers showing several diameters (Figure 2I). In the vascular region there are secondary phloem and xylem, followed by the parenchymatous medulla cells in the center of stem (Figure 2J).
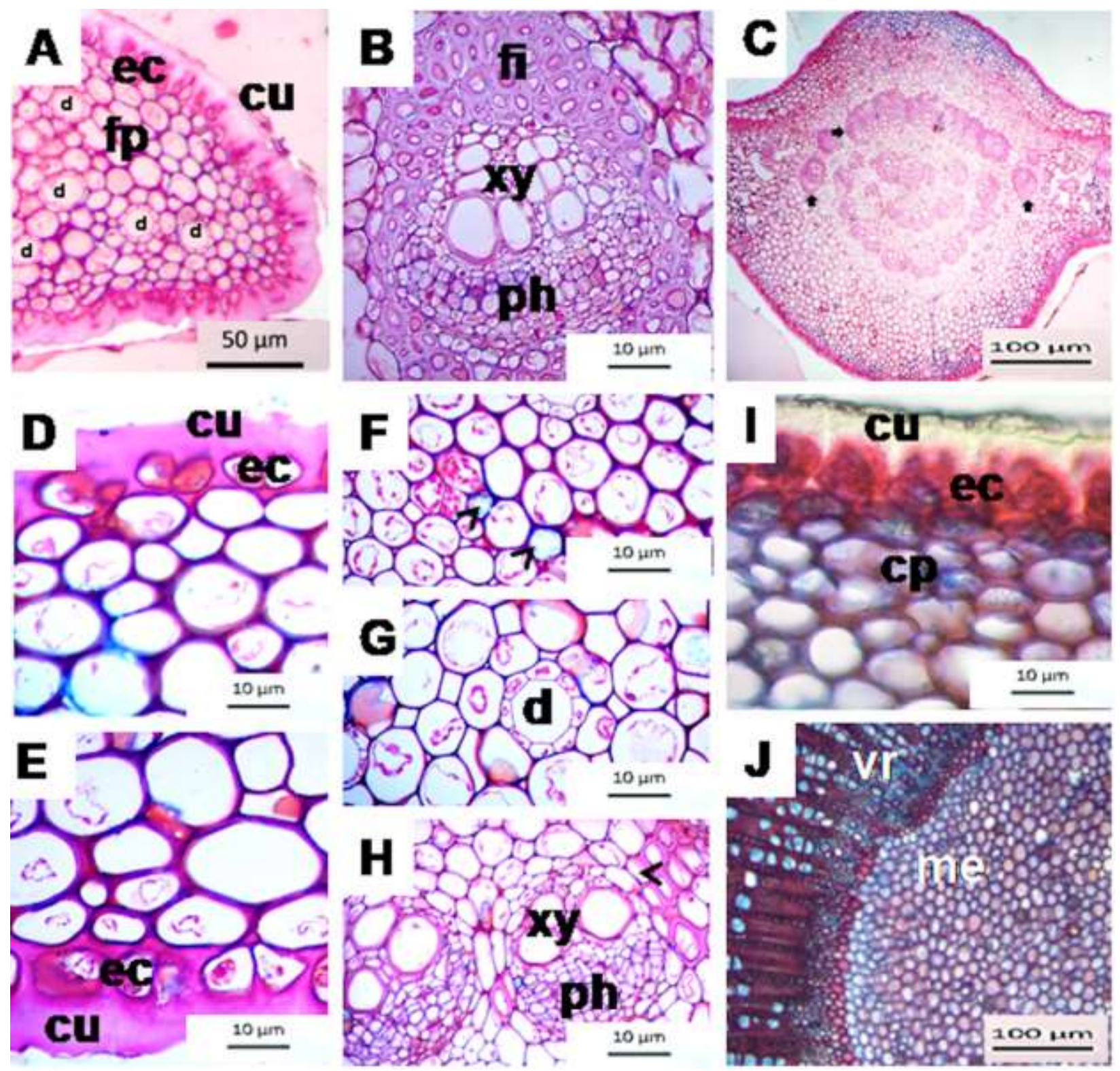

Figure 2. Clusia grandiflora in cross-sections. A-B. Edge of leaf, C-H Midrib and I-J. Stem. A) Detail of the leaf edge showing the cuticle and secretory ducts. B) Vascular bundle of leaf edge. C) Overview of the midrib showing vascular system, free circular bundles and perivascular fibers (arrow). D - E) Cuticle with flanges and internal periclinal wall cutinized in adaxial and abaxial view. F) Idioblast with druse (arrow). G) Secretory duct. H) Detail of vascular bundles and perivascular fibers (arrow). I) Detail of uniseriate epidermis of the stem. J) Secondary xylem and medulla region. cp: cortical parenchyma; cu: cuticle; d: secretory ducts; ec: epidermal cells; fi: fibers; fp: fundamental parenchyma; me: medulla; ph: phloem; vr: vascular region; xy: xylem. Scale: $A=50 \mu \mathrm{m} ; \mathrm{B}, \mathrm{D}-\mathrm{I}=10 \mu \mathrm{m} ; \mathrm{C}$ and $\mathrm{J}=100 \mu \mathrm{m}$.

\section{Histochemical analysis}

Wagner's reagent was positive indicating the presence of alkaloids in epidermal cells and vascular bundle in all parts of the leaf (Table 1) (Figure 3A). 
Lugol and calcofluor detected storage carbohydrates, such as polysaccharides (starch), and structural polysaccharides (cellulose). Starch grains were observed in all parts of the leaf and stem, mainly in the cortical and medullary parenchyma of the petiole, in all central midrib (Figure 3B) and in the spongy parenchyma of the intercostal region (Table 1). The cellulose was evidenced in the spongy parenchyma and epidermal cells of the intercostals region, with more emphasis on the latter (Table 1) (Figure 3C).

Lipid substances and their derivatives were evidenced by Sudan III, Sudan IV and Auramine O. Sudan III and IV stain the leaf and stem, mainly in all leaf cuticle (Figure 3D), idioblasts present in the cortical and medullar parenchyma of the midrib, in the cortical parenchyma of the petiole, in the fundamental parenchyma of the edge of leaf and in the cortical parenchyma of the stem (Table 1). The Auramine O fluorophore was evident in the leaf cuticle (Table 1) (Figure 3E).

Phenol substances were stained with ferric chloride and detected in the palisade parenchyma of the intercostal region (Figure 3F), in the fundamental parenchyma of the leaf edge, vascular system of the petiole and in the cortical region of the stem (Table 1).

Tannins and flavonoids were not detected by histochemical tests with chloridric vanillin and aluminum chloride, respectively (Table 1 ).

Table 1.Reagents for detection of primary and secondary metabolites and localization of the chemical classes detected in the leaf blade and in the stems of Clusia grandiflora by histochemical tests.

\begin{tabular}{ccccccc}
\hline Chemical class & Reagent & Petiole & Edge & $\begin{array}{c}\text { Intercostal } \\
\text { region }\end{array}$ & Midrib & Stem \\
\hline Lipophilic substances & Sudan III [17] & + & + & + & + & + \\
& Sudan IV [17] & + & + & + & + & + \\
& Auramine O [20] & + & + & + & + & $\mathrm{n}$ \\
\hline Flavonoids & Aluminum chloride [21] & - & - & - & - & - \\
\hline Alkaloids & Wagner's reagent [22] & + & + & + & + & - \\
\hline Tannins & Chloridric vanillin [23] & - & - & - & - & - \\
\hline Phenols substances & Ferric chloride [17] & + & + & + & - & + \\
\hline Carbohydrates: & & & & & & \\
Starch & Lugol [17] & + & + & + & + & + \\
Cellulose & Calcofluor [24] & - & - & + & - & $\mathrm{n}$ \\
\hline
\end{tabular}

+ present, - absent, n: test not performed. 

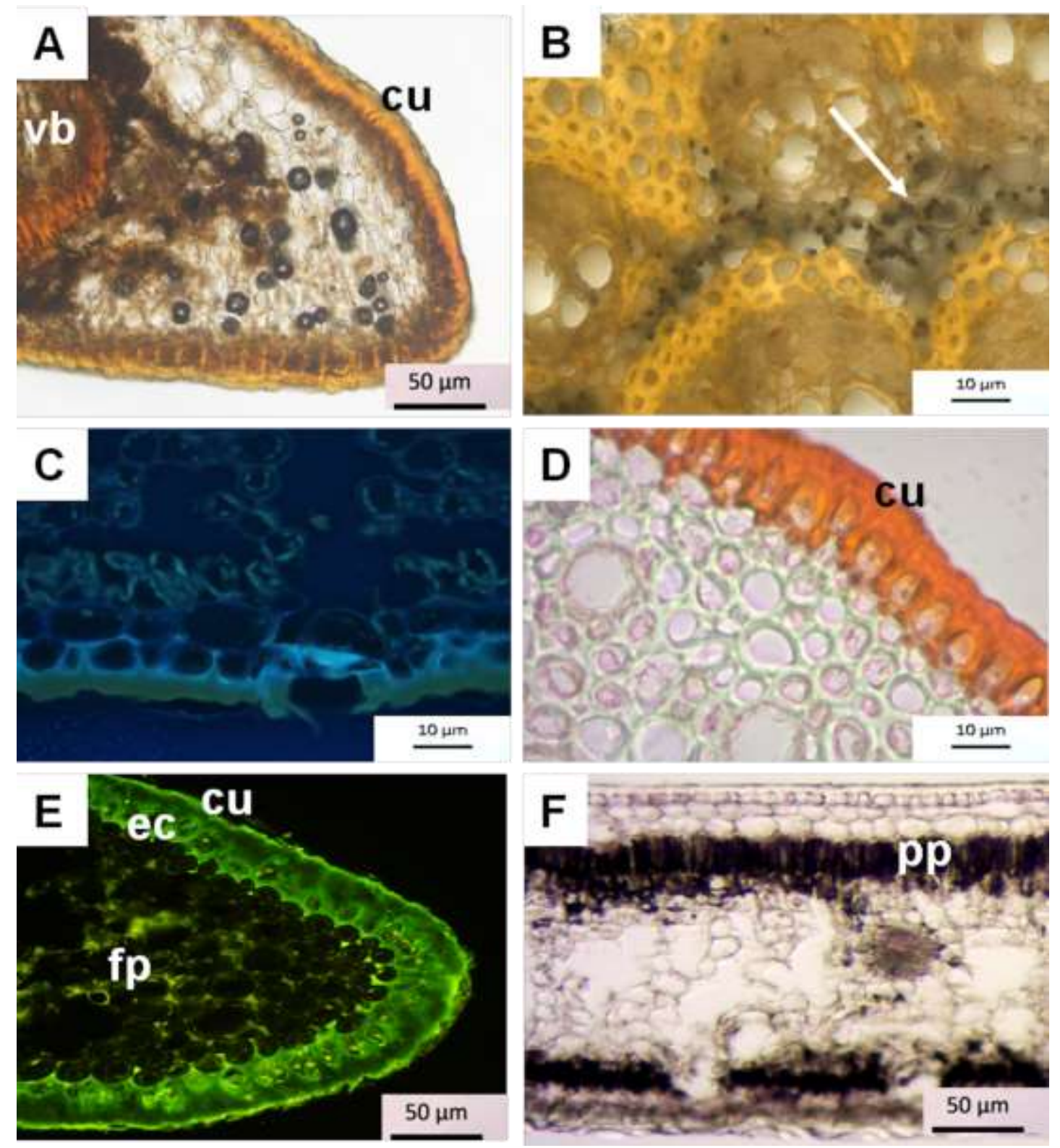

Figure 3. Histochemical tests of leaf and stem of Clusia grandiflora. A) Epidermis and vascular bundle stained with Wagner's reagent on the leaf edge suggesting the presence of alkaloids. B) Medullar parenchyma of the midrib, next to the vascular cylinder, stained with Lugol indicating the presence of starch (arrow). C) Leaf blade evidencing the presence of cellulose in the epidermis stained with calcofluor. D) Cuticle of the petiole stained with Sudan IV indicating the presence of lipids. E) Leaf edge evidencing the presence of lipids in cuticle when stained with Auramine O. F) Palisade parenchyma of the intercostal region stained with ferric chloride evidencing the presence of phenolic substances. cu: cuticle; ec: epidermal cells; fp: fundamental parenchyma; pp: palisade parenchyma; vb: vascular bundle. Scale: A, E and $\mathrm{F}=50 \mu \mathrm{m}, \mathrm{B}, \mathrm{C}$ and $\mathrm{D}=10 \mu \mathrm{m}$.

\section{Preparation of the extract}

Adventitious roots, stems, leaves and flowers of $C$. grandiflora were collected, processed and subjected to successive extraction with hexane and ethanol. Results with extractive yields are shown in Table 2. 
Table 2. Plant part, dry weight $(\mathrm{g})$, solvent $(\mathrm{mL})$, extract weight $(\mathrm{g})$, yield $(\%)$ and sample code of the process of extraction of Clusia grandiflora.

\begin{tabular}{|c|c|c|c|c|c|}
\hline Plant part & Dry weight (g) & Solvent (mL) & Extract weight (g) & Yield (\%) & Sample code \\
\hline \multirow[t]{2}{*}{ Flowers } & \multirow[t]{2}{*}{31.60} & Hexane (100) & 0.41 & 1.30 & CGFH \\
\hline & & Ethanol (100) & 2.49 & 7.88 & CGFEt \\
\hline \multirow[t]{2}{*}{ Adventitious roots } & \multirow[t]{2}{*}{45.58} & Hexane (100) & 1.34 & 2.93 & CGRAH \\
\hline & & Ethanol (100) & 2.16 & 4.74 & CGRAEt \\
\hline \multirow[t]{2}{*}{ Stems } & \multirow[t]{2}{*}{887.10} & Hexane (1000) & 7.41 & 0.84 & CGRH \\
\hline & & Ethanol (1000) & 26.69 & 3.00 & CGREt \\
\hline \multirow[t]{2}{*}{ Leaves } & \multirow[t]{2}{*}{1126.95} & Hexane (1500) & 25.15 & 2.23 & CGFoH \\
\hline & & Ethanol (1500) & 51.28 & 4.55 & CGFoEt \\
\hline
\end{tabular}

\section{Anticancer and hemolytic activity}

In vitro cytotoxicity showed positive results for ethanolic extracts of stem and leaves against the human colon and gastric ascites, respectively. In addition, the absence of hemolytic activity was verified. Results are shown in Table 3.

Table 3. $\mathrm{IC}_{50}$ values obtained to the cytotoxic and hemolytic assays of the crude extracts of Clusia grandiflora.

\begin{tabular}{|c|c|c|c|c|c|}
\hline \multirow[t]{2}{*}{ Sample code } & \multicolumn{5}{|c|}{$\mathrm{IC}_{50}(\mu \mathrm{g} / \mathrm{mL} \text { e } \mu \mathrm{M})^{\star}$} \\
\hline & HCT-116 & AGP-01 & MCF7 & MRC5 & Hemolysis \\
\hline CGFH & $>50$ & $>50$ & $>50$ & $>50$ & $>200$ \\
\hline CGFEt & $>50$ & $>50$ & $>50$ & $>50$ & $>200$ \\
\hline CGRAH & $>50$ & $>50$ & $>50$ & $>50$ & $>200$ \\
\hline CGRAEt & $>50$ & $>50$ & $>50$ & $>50$ & $>200$ \\
\hline CGRH & $>50$ & $>50$ & $>50$ & $>50$ & $>200$ \\
\hline CGREt & $\begin{array}{c}24.30(18.54- \\
31.84)\end{array}$ & $>50$ & $>50$ & $>50$ & $>200$ \\
\hline CGFoH & $>50$ & $>50$ & $>50$ & $>50$ & $>200$ \\
\hline CGFoEt & $>50$ & $\begin{array}{c}44.15(34.79- \\
56.02)\end{array}$ & $>50$ & $>50$ & $>200$ \\
\hline Doxorubicin & $0.95(0.73-1.24)$ & $0.25(0.19-0.33)$ & $0.1(0.047-0.28)$ & $0.2(0.16-0.25)$ & $>200$ \\
\hline
\end{tabular}

*the concentration values are in $\mu \mathrm{g} / \mathrm{mL}$ for the extracts and in $\mu \mathrm{M}$ for Doxorubicin. HCT-116: human colon, AGP-01: gastric ascites; MCF7: breast-human; MRC5: human fibroblast; CGFH: hexanic extract of flowers; CGFEt: ethanolic extract of flowers; CGRAH: hexanic extract of adventitious roots; CGRAEt: ethanolic extract of adventitious roots; CGRH: hexanic extract of stem; CGREt: ethanolic extract of stem; CGFoH: hexanic extract of leaves; CGFoEt: ethanolic extract of leaves.

\section{Antibacterial activity}

The extracts showed antibacterial activity in the TSA assay only for the Gram negative strains of Pseudomonas aeruginosa and Escherichia coli for five of the eight tested extracts, as shown in Table 4.

Table 4.Diameter of the inhibition halos formed as a function of the extracts $(5 \mathrm{mg} / \mathrm{mL})$ of Clusia grandiflora activity against Pseudomonas aeruginosa and Escherichia coli strains.

\begin{tabular}{ccc}
\hline Sample code & P. aeruginosa & E. coli \\
\hline CGFH & - & - \\
\hline CGFEt & $6.3 \mathrm{~mm}$ & $6.6 \mathrm{~mm}$ \\
\hline CGRAH & - & - \\
\hline CGRAEt & $7.0 \mathrm{~mm}$ & $7.0 \mathrm{~mm}$ \\
\hline CGRH & $7.6 \mathrm{~mm}$ & $7.8 \mathrm{~mm}$ \\
\hline CGREt & $6.6 \mathrm{~mm}$ & $7.0 \mathrm{~mm}$ \\
\hline CGFoH & - & - \\
\hline CGFoEt & $7.3 \mathrm{~mm}$ & $6.2 \mathrm{~mm}$ \\
\hline
\end{tabular}

- without halo formation. CGFH: hexanic extract of flowers; CGFEt: ethanolic extract of flowers; CGRAH: hexanic extract of adventitious roots; CGRAEt: ethanolic extract of adventitious roots; CGRH: hexanic extract of stems; CGREt: ethanolic extract of stems; CGFoH: hexanic extract of leaves; CGFoEt: ethanolic extract of leaves.

The extracts that showed activity in the TSA assay had their MIC determined and the results were expressed in Table 5. 
Table 5.Minimal inhibitory concentrations (MIC) of the active extracts (256 to $0.25 \mu \mathrm{g} / \mathrm{mL}$ ) of Clusia grandiflora against Pseudomonas aeruginosa and Escherichia coli strains.

\begin{tabular}{ccc}
\hline Sample code & P. aeruginosa & E. coli \\
\hline CGFEt & $256 \mu \mathrm{g} / \mathrm{mL}$ & $64 \mu \mathrm{g} / \mathrm{mL}$ \\
\hline CGRAEt & $32 \mu \mathrm{g} / \mathrm{mL}$ & $16 \mu \mathrm{g} / \mathrm{mL}$ \\
\hline CGRH & $256 \mu \mathrm{g} / \mathrm{mL}$ & $128 \mu \mathrm{g} / \mathrm{mL}$ \\
\hline CGREt & $64 \mu \mathrm{g} / \mathrm{mL}$ & $32 \mu \mathrm{g} / \mathrm{mL}$ \\
\hline CGFoEt & $64 \mu \mathrm{g} / \mathrm{mL}$ & $32 \mu \mathrm{gL} / \mathrm{mL}$
\end{tabular}

CGFH: hexanic extract of flowers; CGFEt: ethanolic extract of flowers; CGRAEt: ethanolic extract of adventitious roots; CGRH: hexanic extract of stems; CGREt: ethanolic extract of stems; CGFoEt: ethanolic extract of leaves.

\section{DISCUSSION}

The anatomical and histochemical studies are useful for the practical identification and characterization of phylogenetic relationships, besides being the first step to identify plant species in the quality control [12, 25-27].

The thick cuticle forming flanges was observed in species of Clusia, including C. hilariana Schltdl.[28,29], C. obdeltifolia Bittrich [30], C. criuva Cambess. [31] and C. Lanceolata Cambess. [32]. In literature, there are no studies of ontogeny that prove the schizogenic origin of the secretory ducts in $C$. grandiflora, although it has already been indicated [33]. Silva and coauthors [34] describes these schizogenic ducts in $C$. fluminensis and $C$. lanceolata, suggesting that they can also occur in $C$. grandiflora.

The vascular system of the petiole was already mentioned by Paula [35] in Clusia aff. macropoda Klotzsch ex Engl., but the accessory bundles were absent, being a unique characteristic of the species.

The hypodermis present in the mesophyll is general in the genus [27] and has already been described in C. aff. macropoda[35], C. hilariana[28], C. spiritu-sanctensis G. Mariz \& B. Weinberg [36] and C. criuva $[2,31]$.

Solereder [37] cited anatomical aspects of the stem common to the family, such as thin medullary rays. Characteristics such as the presence of epidermis in structure with secondary growth have also been observed in C. aff. macropoda[35].

Histochemical studies suggested the presence of alkaloids in C. grandiflora. In C. criuva alkaloids were also identified in histochemical studies and in the chemical profile [31], but the isolation of this type of secondary metabolite in Clusia species has still not been described in the literature.

The presence of carbohydrates, the primary metabolite essential for plant survival, was observed. Two types of polysaccharides were verified, the structural cellulose and the storage starch, which was found in all parts of the species, corroborating the literature [38].

Phenolic substances were also observed in this histochemical study. They have already been described in previous studies[10] and could be associated with the antioxidant activity and the presence of arylpropanoids in the species.

Flavonoids were little evidenced by the methodology used in this work. Although they were identified and isolated from species of Clusia[3,39,40], in C. grandiflora they were present in low levels, represented by flavones and flavonols [10].

Regarding the cytotoxic activity against cancer cell lines, the most promising extracts were those extracted in ethanol. The extract of stems presented a good anticancer activity for the human colon line and the extract of the leaves for the gastric ascite cell line. The extracts were active only for the tumor cell line and did not inhibit normal line growth at the tested concentrations. According to the National Cancer Institute protocol [41], $\mathrm{IC}_{50}$ values $\leq 30 \mathrm{\mu g} / \mathrm{mL}$ should be considered promising for crude extracts of plant origin.

The study performed for the determination of hemolytic activity in mice cells indicated that none of the samples tested lysed the plasma membrane of the cells at the highest concentration tested. Thus, it was not the mechanism of action of the extracts and future studies should be realized.

The cytotoxic activity of Clusia has already been described in literature, being benzophenones the secondary metabolites with the highest action. Nemorosone, present in $C$. rosea Jacq., was cytotoxic to different tumor cell lines and with low cytotoxicity in healthy cells [4,42-45]. Biphenyl derivatives present in $C$. paralicola G. Mariz also showed cytotoxicity in general tumor cell underlining that form keratin [46]. However, phenolic compounds could also be involved with this biological activity since it has already been described in the literature with the anticancer activity [47]. 
Five extracts, four of them ethanolic, showed activity against Pseudomonas aeruginosa and Escherichia coli in TSA. This result is quite promising because it is a crude extract composed of several substances in small concentrations that may be contributing synergistically and reducing the chances of resistance [48].

Adventitious roots ethanolic extract was the most effective against $P$. aeruginosa and $E$. coli. However, all extracts tested for MIC were within the range accepted by the Clinical and Laboratory Standards Institute $(512 \mu \mathrm{g} / \mathrm{mL}>\mathrm{MIC}>0.25 \mu \mathrm{g} / \mathrm{mL})[24]$ and were considered promising.

Previous studies on $C$. grandiflora have shown that benzophenones have antibacterial activity against honey pathogens Paenibacillus larvae and Paenibacillus alvei [9] and floral resins showed antimicrobial activity against Staphylococcus aureus, Bacillus subtilis and Candida albicans in a bioautography test [8]. This assay showed that not only the components of flower resins may exhibit antibacterial activity but also from other parts of $C$. grandiflora and compounds with polar features. Naves and coauthors [49] have already related that leaf aqueous extract from Garcinia brasiliensis Mart. (Clusiaceae), with high content of phenolic compounds, displayed a great antimicrobial activity.

\section{CONCLUSION}

The notable anatomical features of $C$. grandiflora included the presence of hypodermis, cuticles with flanges and secretory ducts. In addition, vascular system of the petiole showed accessory bundles, being a unique characteristic of the species. Histochemical tests demonstrated the presence of alkaloids, starch grains, lipids and phenols substances. These findings will be useful in the authentication of raw materials of the species.

The cytotoxic activity was promising for stems and leaves ethanolic extracts against the human colon and gastric ascites lines, respectively. The extracts presented antibacterial activity against the strains of $P$. aeruginosa and $E$. coli, with all ethanolic extracts being outstanding. The activities evaluated showed the potential of the species for the isolation of promising compounds with polar features and also contributed to increase the knowledge of the genus Clusia and, thus, the Brazilian flora.

Funding:This research was funded by Coordenação de Aperfeiçoamento de Pessoal de Nível Superior, grantnumber 001 and Fundação Carlos Chagas Filho de Amparo à Pesquisa do Estado do Rio de Janeiro, grantnumber 26/200.930/2017.

Acknowledgments: The authors thank the Fluminense Federal University (UFF) and Jardim Botânico do Rio de Janeiro Research Institute (JBRJ).

Conflicts of Interest: The authors declare no conflict of interest. The funders had no role in the design of the study; in the collection, analyses, or interpretation of data; in the writing of the manuscript, or in the decision to publish the results.

\section{REFERENCES}

1. Stevens PF. Angiosperm phylogeny website. Missouri: Missouri Botanical Garden \& University of Missouri; 2001 onwards, Version 14, July 2017 (and more or less continuously updated since), [cited 2019 Nov 11]. Available from: <http://http://www.mobot.org/MOBOT/research/APweb>.

2. Fernandes SDC. Morfologia, anatomia, histoquímica e aspectos fisiológicos da lâmina foliar de espécies de Clusia (Clusiaceae). Brasília, 134f. Dissertação de Mestrado, Programa de Pós-Graduação em Botânica. 2007.

3. Bittar M, De Souza MM, Yune, RA, Lento R, Delle-Monache F, Cechinel-Filho V. Antinociceptive activity of I3, II8binaringenin, a biflavonoid present in plants of the Guttiferae. Planta Med. 2000; 66: 84-6.

4. Cuesta-Rubio O, Frontana-Uribe BA, Ramirez-Apan T, Cardenas J. Polyisoprenylated benzophenones in Cuban propolis; biological activity of nemorosone. Z. Naturforsch C J Biosci. 2002; 57: 372-8.

5. Kelecom A, Reis GL, Fevereiro PCA, Silva JG, Santos MG, Mello-Neto CB, et al. A multidisciplinary approach to the study of the fluminense vegetation. An Acad Bras Cienc. 2002; 74: 171-81.

6. Langenheim J.H. Plant resins: chemistry, evolution, ecology and ethnobotany. Hong Kong: Timber Press; 2003.

7. Lokvam J, Braddock JF. Anti-bacterial function in the sexually dimorphic pollinator rewards of Clusia grandiflora (Clusiaceae). Oecologia. 1999; 119: 534-40.

8. Porto ALM, Machado SMF, De Oliveira CMA, Bittrich V, Amaral MDCE, Marsaioli AJ. Polyisoprenylated benzophenones from Clusia floral resins. Phytochemistry. 2000; 55: 755-68.

9. Lokvam J, Braddock JF, Reichardt PB, Clausen TP. Two polyisoprenylated benzophenones from the trunk latex of Clusia grandiflora (Clusiaceae). Phytochemistry. 2000; 55: 29-34.

10.Ribeiro MMJ, Macedo AL, Anholeti MC., Lobão AQ, Valverde AL, Paiva SR. Atividade antioxidante, doseamento de flavonoides e perfil químico em extratos de Clusia grandiflora (Clusiaceae). Ver Bras Plant Med. 2017; 19: 443-9. 
11.Coelho VPM, Leite JPV, Nunes LG, Ventrella MC. Anatomy, histochemistry and phytochemical profile of leaf and stem bark of Bathysa cuspidate (Rubiaceae). Austral J Bot. 2012; 60: 49-60.

12.Judd WS, Campbell CS, Kellog EA, Stevens PF. Plant Systematics - a phylogenetic approach. Sunderland: Sinauer Associates; 1999.

13.WHO (World Health Organization). Cancer. Geneva; WHO; 2019, [cited 2019 May 31]. Available from: https://www.who.int/news-room/fact-sheets/detail/cancer>.

14. Thom KA, Kleinberg M, Roghmann MC. Infection prevention in the cancer center. Clin Infect Dis. 2013; 57: 579-85.

15. Felício MR, Silva ON, Gonçalves S, Santos NC, Franco O.L. Peptides with dual antimicrobial and anticancer activities. Front Chem. 2017; 5: 5.

16.Burger LM, Richter HG. Anatomia da Madeira. São Paulo: Nobel; 1991.

17.Johansen DA. Plant microtechnique. New York: Ed. Mc Grawn-Hill Book Company Inc.; 1940.

18. Mosman T. Rapid colorimetric assay for cellular growth and survival: application to proliferation and cytotoxicity assays. J Immunol Methods. 1983; 65: 55-63.

19. Clinical and Laboratory Standards Institute. Methods for Dilution Antimicrobial Susceptibility Tests for Bacteria That Grow Aerobically. Pennsylvania: Clinical and Laboratory Standards Institute; 2012.

20.Considine JA, Knox RB. Development and histochemistry of the cells, cell walls, and cuticle of the dermal system of fruit of the grape, Vitis vinifera L. Protoplasma. 1979; 99: 347-365.

21.Charrière-Ladreix Y. Répartition intracellulaire du secrétat flavonique de Populus nigra L. Planta. 1976;129:167-74.

22. Furr M, Mahlberg PG. Histochemical analyses of lacticifers and glandular trichomes in Cannabis sativa. J Nat Prod. 1981;44:153-9.

23. Mace ME, Howell CR. Histochemistry and identification of condensed tannin precursor in roots of cotton seedlings. Can J Botany. 1974; 52: 2423-6.

24. Herth W, Schnepf E. The fluorochrome, calcofluor white, binds oriented to structural polysaccharide fibrils. Protoplasma. 1980; 105: 129-33.

25. Duarte MR, Menarim DO. Morfodiagnose da anatomia foliar e caulinar de Camellia sinensis (L.) Kuntze, Theaceae. Rev. Bras. Farmacogn. 2006; 16: 545-51.

26. Ferreira LA, Leite JPV. Desenvolvimento de formulações fitoterápicas. In: Leite, JPV. Fitoterapia: bases científicas e tecnológicas. São Paulo: Atheneu; 2009. p. 205-51.

27. Metcalfe CR, Chalk L. Anatomy of dicotyledons: leaves, stem, and wood in relation to taxonomy with notes on economic uses. Oxford: Clarendon Press; 1950.

28. Silva LC, Oliva MA, Azevedo AA, Araújo JM, Aguiar RM. Micromorphological and anatomical alterations caused by simulated acid rain in restinga plants: Eugenia uniflora and Clusia hilariana. Water Air Soil Poll. 2005;168:129-43.

29. Rocha DI, Da Silva LC, Pereira EG, Sant'anna-Santos BF, Gontijo ER, Oliva MA. Early detection of injuries in leaves of Clusia hilariana Schltdl. (Clusiaceae) caused by particulate deposition of iron. Rev Arvore. 2014;38:423-32.

30. Silva C, Leite K, Ferreira L, Silva M, Silva L. Influência da altitude na plasticidade foliar de Clusia obdeltifolia Bittrich (Clusiaceae). Revista Nordestina de Biologia. 2014;23:29-48.

31. Silva KMM, Nóbrega AB, Lessa B, Anholeti MC, Lobão AQ, Valverde AL, et al. Clusia criuva Cambess.(Clusiaceae): anatomical characterization, chemical prospecting and antioxidant activity. An Acad Bras Cienc. 2017;89:1565-78.

32. Guimarães ALA, Bizarri CHB, Barbosa LS, Nakamura MJ, Ramos MFS, Vieira ACM. Characterisation of the effects of leaf galls of Clusia myianitida (Cecidomyiidae) on Clusia lanceolata Cambess. (Clusiaceae): Anatomical aspects and chemical analysis of essential oil. Flora. 2013;208:165-73.

33.Paula JE. Notas sobre anatomia de Clusia grandiflora Splitg. (Guttiferae). Inst Nac Pesq Amaz Bot. 1966; 22: 1-24.

34. Marins KMS, Luna BN, Joffily A, Paiva SR, Barros CF. Revealing the development of secretory structures in the leaves of Clusia fluminensis and Clusia lanceolata (Clusiaceae). Flora.2019;256:69-78.

35.Paula JE. Anatomia de Lorostemon coelhoi Paula, Caraipa valioi Paula e Clusia aff.macropodaKlotzch. Acta Amazon. 1976;6:273-91.

36.Schneider SZ. Anatomia foliar de Clusia hilariana Schlechtendal e Clusia spiritu-sanctensis G. Mariz et Weinberg (Guttiferae) ocorrentes no estado do Espírito Santo. Rio de Janeiro 163p. Dissertação de Mestrado, Universidade Federal do Rio de Janeiro. 1985.

37. Solereder H. Systematic anatomy of dicotyledons. Oxford: Claredon Press; 1908.

38. Esau K. Anatomia das plantas com semente. São Paulo: E. Blucher; 1974.

39.Ferreira RO, Junior ARC, Silva TMG, Castro RN, Silva TMS, Carvalho MG. Distribution of metabolites in galled and non-galled leaves of Clusia lanceolata and its antioxidant activity. Rev Bras Farmacogn. 2014; 24: 617-25.

40. Oliveira RF, Camara CA, Agra MDF, Silva TMS. Biflavonoids from the unripe fruits of Clusia paralicola and their antioxidant activity. Nat Prod Commun. 2012; 7: 1597-1600. 
41.Alley MC, Scudiero DA, Monks-Hursey ML, Czerwinski MJ, Fine DL, Abbott BJ, et al. Feasibility of drug screening with panels of human tumor cell lines using a microculture tetrazolium assay. Cancer Res. 1988; 48: 589-601.

42. Diaz-Carballo D, Seeber S, Strumberg D, Hilger RA. Novel antitumoral compound isolated from Clusia rosea. Int J Clin Pharmacol Ther. 2003;41 622-33.

43.Diaz-Carballo D, Malak S, Bardenheuer W, Freistuehler M, Reusch HP. Cytotoxic activity of nemorosone in neuroblastoma cells. J Cell Mol Med. 2008a. 12:2598-2608.

44.Diaz-Carballo D, Malak S, Freistuhler M, Elmaagacli A, Bardenheuer W, Reusch HP. Nemorosone blocks proliferation and induces apoptosis in leukemia cells. Int J Clin Pharmacol Ther. 2008b;46:428-39.

45.Popolo A, Piccinelli AL, Morello S, Sorrentino R, Osmany CR, Rastrelli L, et al. Cytotoxic activity of nemorosone in human MCF-7 breast cancer cells. Can J Physiol Pharmacol. 2011;89:50-7.

46.Seo, EK, Huang L, Wall ME, Wani MC, Navarro H, Mukherjee R, et al. New biphenyl compounds with DNA strandscission activity from Clusia paralicola. J Nat Prod. 1999;62:1484-87.

47. Riahi-chebbi I, Souid S, Othman H, Haoues M, Karoui H, Morel A, Srairi-Abid N, et al. The Phenolic compound Kaempferol overcomes 5-fluorouracil resistance in human resistant LS174 colon cancer cells. Sci Rep. 2019;9:195.

48. Da Silva MCA. Produtos do metabolismo especial de Clusia fluminensis Planch. \&Triana. Niterói, 110p. Dissertação de Mestrado, Programa de Pós-Graduação em Ciências Farmacêuticas. 2011.

49. Naves VML, Dos Santos MH, Ribeiro IS, Da Silva CA, Silva NC, Da Silva MA, et al. Antimicrobial and antioxidant activity of Garcinia brasiliensis extracts. S Afr J Bot. 2019;124:244-50.

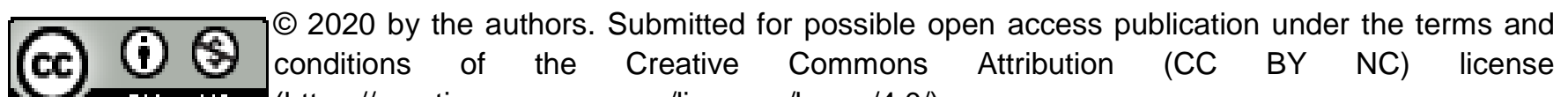
EY NC (https://creativecommons.org/licenses/by-nc/4.0/). 